\title{
KAJIAN PERUBAHAN RUANG DAN SOUNDMARK KAWASAN WISATA PUSAKA TAMANSARI YOGYAKARTA
}

\author{
Patricia Pahlevi Noviandri ${ }^{1}$, Ferdy Sabono ${ }^{2}$ \\ 1,2. Program Studi Arsitektur, Fakultas Arsitektur dan Desain, Universitas Kristen Duta Wacana, \\ Jl. dr. Wahidin Sudirohusodo No. 5-25, Yogyakarta \\ Email: patriciapahlevi@staff.ukdw.ac.id
}

\begin{abstract}
Abstrak
Kawasan Tamansari merupakan kawasan yang bernilai sejarah. Sampai saat ini, kawasan ini dikonservasi dan digunakan sebagai wisata pusaka. Situs Tamansari yang sudah tidak digunakan lagi sejak masa pemerintahan Sultan Hamengkubuwono III menyebabkan tumbuhnya perumahan penduduk di sekitarnya. Hal ini yang menimbulkan terjadinya perubahan solid void kawasan Tamansari. Perubahan tatanan bangunan yang ada menimbulkan perbedaan soundscape pada kawasan yang dulunya merupakan lokasi peristirahatan Keraton dan sekarang menjadi kawasan wisata pusaka. Dalam penelitian in akan membahas mengenai perubahan yang terjadi pada tata massa bangunan di kawasan Tamansari yang akan mempengaruhi akustik lingkungan kawasan tersebut. Metode penelitian ini menggunakan metode deduktif kualitatif dengan membandingkan bentuk ruang pada masa aktif bangunan sebagai peristirahatan keluarga Keraton dengan tata massa bangunan pada saat ini yang dibahas dengan teori ruang dan akustik lingkungan. Hasil dari penelitian ini yaitu perubahan figure ground dan linkage memperlihatkan perubahan soundmark kawasan Tamansari. Figure ground yang berubah membuat dampak munculnya aktivitas yang semakin beragam. Soundmark berubah dari dominan suara tenang menjadi dominan nois. Soundmark kawasan berubah dari suara-suara yang mendukung suasana sakral dengan suara-suara yang akibat kepadatan bangunan. Perubahan soundmark ini menciptakan perubahan sense of place dari kawasan Tamansari.
\end{abstract}

Kata kunci: akustik lingkungan, figure ground, Kawasan Tamansari, soundscape, soundmark.

\begin{abstract}
Title: Study of Space Changing and Soundmark in Tamansari Heritage Tourism Area, Yogyakarta

Tamansari area is an area of historical value. Until now, this region has been conserved and used as a heritage tourism. The Tamansari site, which has not been used anymore since the reign of Sultan Hamengkubuwono III, has caused the growth of residential areas around it. This causes a change in the solid void of the Tamansari area. Changes in the existing building structure create differences in the soundscape of the area that was once the location of the palace retreat and is now a heritage tourism area. In this study will discuss the changes that occur in the mass management of buildings in the Tamansari area that will affect the environmental acoustics of the area. This research method uses qualitative deductive method by comparing the shape of the space during the active period of the building as the resting of the Keraton family with the current building mass discussed with the theory of space and acoustic environment. The results of this study are changes in ground figures and linkages showing changes in the soundmark of the Tamansari area. Changing ground figures make the impact of increasingly diverse activities appear. Soundmark changed from the dominant calm voice to the nois dominant. The soundmark area changes from sounds that support a sacred atmosphere with sounds that are due to building density. This change in soundmark creates a change of sense of place from the Tamansari area.
\end{abstract}

Keywords: environment acoustics, figure ground, Tamansari, soundscape, soundmark. 


\section{Pendahuluan}

Ruang menurut Aristoteles dan Einstein (Van de Ven, 1991) merupakan suatu tempat yang memiliki elemen fisik yang dapat berupa nama / tatanan objek material secara umum. Dalam jangka beberapa waktu, ruang selalu berubah. Perubahan ruang terkait dengan perubahan aktivitas yang ada di sebuah tempat. Perubahan aktivitas yang terjadi pada kawasan Situs Tamansari mengakibatkan timbulnya perubahan ruang yang ada.

Pada mulanya, Tamansari merupakan situs bekas taman atau kebun istana Keraton Ngayogyakarta Hadiningrat. Kebun ini dibangun pada masa pemerintahan Sultan Hamengku Buwono I pada tahun 1758 1765/9. Pada awalnya taman ini memiliki luas lebih dari $10 \mathrm{Ha}$ dengan bangunan seperti gedung, kolam pemandian, jembatan gantung, kanal air, dan danau buatan beserta pulau buatan serta lorong bawah tanah. Tamansari didirikan diatas sebuah umbul atau mata air yang dikenal dengan nama Umbul Pacethokan. Tamansari sebagai kebun kerajaan tetapi beberapa bangunan yang ada di Tamansari memperlihatkan bahwa Tamansari berfungsi sebagai benteng pertahanan akhir apabila istana diserang oleh musuh.

Sejak tahun 1867 situs Tamansari tidak digunakan lagi karena air segaran menghilang dan banyak bangunan rusak akibat gempa tektonik yang terjadi di Yogyakarta pada tahun tersebut. Oleh sebab itu, pihak Kraton mengijinkan masyarakat (abdi dalem dan keluarganya) untuk tinggal di Tamansari. Pertumbuhan pemukiman di kawasan Tamansari terbentuk secara sporadis tanpa ada penataan khusus. Rumah-rumah penduduk tersebut terdapat yang menempel pada situs dan berada di atas situs tersebut. Hal ini yang menyebabkan tidak terlihatnya situs Tamansari saat ini dengan jelas.
Kawasan Tamansari ditentukan sebagai kawasan yang dikenai penanganan dengan pendekatan konsep konservasi, yaitu mempertahankan kekhasan dari bekas Kraton dan sekitarnya (Subhekti, 2005). Tamansari merupakan sebuah Kawasan Cagar Budaya menurut pasal 9 dan pasal 10 UURI No. 11 / 2010 tentang kriteria situs dan kawasan Cagar Budaya. Konsep konservasi yang dimaksudkan menurut piagam Burra pasal 1 ayat 3 adalah seluruh proses pemeliharaan sebuah tempat untuk mempertahankan signifikansi budayanya. Menurut Winarni (2006), pada tahun 1992 diadakan pemugaran area Tamansari sebagai bagian dari usaha konservasi, setelah dilakukan pemugaran dikeluarkannya Dawuh Dalem angka 009/DD-J/2004 dari Sri Sultan Hamengku Buwono $\mathrm{X}$ mengenai tindak lanjut pengelolaan Tamansari dengan membentuk Badan Pelestarian Tamansari.

Dalam konservasi Tamansari yang telah dilakukan merupakan upaya konservasi secara fisik. Namun, kekhasan terkait suasana semakin lama semakin tidak terlihat dan terus tergeser dengan suasana wisata modern di kawasan tersebut.

Seseorang mendapatkan pengalamanpengalaman inderawi pada hidupnya yang memberikan makna pada suatu tempat pada saat dia lahir. Seseorang tidak dapat langsung menyadari pengalamanpengalaman inderawi tersebut tetapi dia akan merasakan secara perlahan. Hakikat ruang merupakan hubungan antara spiritual dengan lingkungan (Visher dalam Cornelis Van de Ven, 1991). Dalam memaknai sebuah ruang perlu adanya hubungan spasial antara pengamat dan objeknya sebagai suatu pengalaman artistik. Ruang menjadi landasan bersama antara tangible culture dan intangible culture. Ruang merupakan suatu place of belonging (Van de Ven, 1991). Manusia mampu memaknai ruang bergantung dengan pengalamanpengalaman inderawi yang pernah 
dirasakan sehingga ruang menjadi milik dari manusia itu sendiri.

Adanya identitas suara yang khas menciptakan Long Term Memory (LTM) bagi manusia yang ada di dalamnya. LTM biasanya terjadi dalam keadaan tidak sadar dan spontan (mengenali) atau dalam keadaan sadar dengan cara mengingat kembali (Synder, 2000). Perubahan pada sebuah ruang akibat intervensi atau tranformasi bentuk spasial memberikan gambaran pemaknaan ruang yang berbeda dari yang seharusnya.

Seperti halnya pada perubahan ruang kawasan Tamansari yang dahulunya memiliki karakter ruang dengan pattern yang luas dengan dominasi ruang-ruang terbuka berupa taman dan area air kini berubah menjadi kawasan Tamansari yang bersinggungan langsung dengan area pemukiman yang tentunya akan memberikan perubahan pada ruang kawasan secara keseluruhan. Hal ini didukung oleh pernyataan Adishakti (1997) mengenai setting ruang kota heritage. Pengaturan ruang kota heritage dilakukan dengan mengeksplorasi dan merancang baik dari dalam maupun luar area yang dikonservasi (gambar 1).

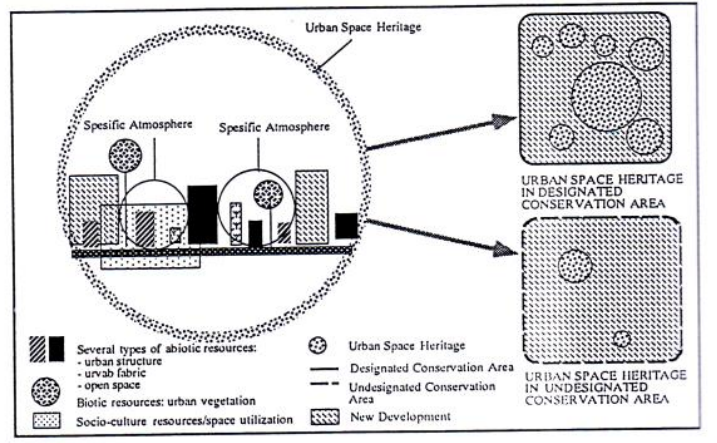

Gambar 1. Ruang kota heritage dan lingkungan sekitar

Sumber : Adishakti, 1997

Selain itu perubahan pemaknaan aktivitas ruang Tamansari yang kini dijadikan sebagai bangunan dengan aktivitas wisata konservasi maka tentunya akan memberikan perbedaan pada unsur-unsur pembentukan kawasan salah satunya adalah dari aspek konservasi akustik.

Hubungan antara perubahan lingkungan dengan akustik lingkungan dapat dilihat dari pernyataan Zhou (2014) yang menyatakan soundscape tidak mungkin ada tanpa lingkungan tertentu, karateristik lingkungan, desain lingkungan dan orangorang di lingkungan adalah semua elemen yang diperlukan dalam memahami soundscape. Soundscape adalah bagian dari akustik lingkungan yang menjelaskan mengenai karakteristik wilayah dan budaya masyarakat yang melibatkan beberapa bidang ilmu. Soundcape mengeksplorasi semua suara dalam suatu lingkungan dalam kompleksitas, perasaan psikologis, makna, dan konteksnya.

Menurut Schafer (1994), terdapat 3 (tiga) elemen dalam soundscape yaitu keynote sounds, signals, dan soundmark. Dalam kajian indentitas sebuah kawasan, elemen soundscape yang digunakan yaitu soundmark untuk analisis kawasan Tamansari. Soundmark dapat dikatakan sebagai identitas suara pada suatu lokasi. Soundmark dapat digunakan untuk menggambarkan perilaku dan kejadian manusia terkait suara, dan mampu mengungkapkan karakteristik lingkungan sekitarnya.

Bila melihat pada tujuan konservasi Tamansari, maka aktivitas konservasi seharusnya tidak hanya ditinjau pada bagaimana mempertahankan aspek fisik tetapi juga pada aspek penunjang yang salah satunya adalah akustik kawasan.

Dengan adanya akustik kawasan maka pemaknaan akan nilai keruangan kawasan Tamansari menjadi sebuah tinjauan konservasi yang lengkap. Untuk itu tujuan dari penelitian ini adalah untuk mengetahui perubahan-perubahan yang ada pada ruang kawasan ditinjau dari bentuk ruangnya dan 
pengaruhnya terhadap soundmark kawasan.

\section{Metode Penelitian}

Metode yang digunakan pada penelitian ini yaitu deduktif kualitatif dengan pendekatan rasionalistik. Penelitian ini memverifikasi teori akustik lingkungan yang terkait dengan landscape / kawasan. Analisis dilakukan dengan membandingkan data figure ground masa lalu dan masa kini di Kawasan Tamansari (tipomorfologi). Perbedaan tersebut kemudian dikaitkan pada teori akustik lingkungan.

Metode pengambilan data soundscape masa kini (2018) adalah sebagai berikut:

1. Pengambilan sampel suara dan figure ground Kawasan Tamansari sampai dengan jalan lokal terdekat (1 layer bangunan dari jalan lokal).

2. Pengambilan sampel suara dilakukan selama 4 kali selam 3 hari pada jam berikut :
i) $08.30-09.30$
ii) $10.00-11.00$
iii) $12.00-13.00$
iv) $14.30-15.30$

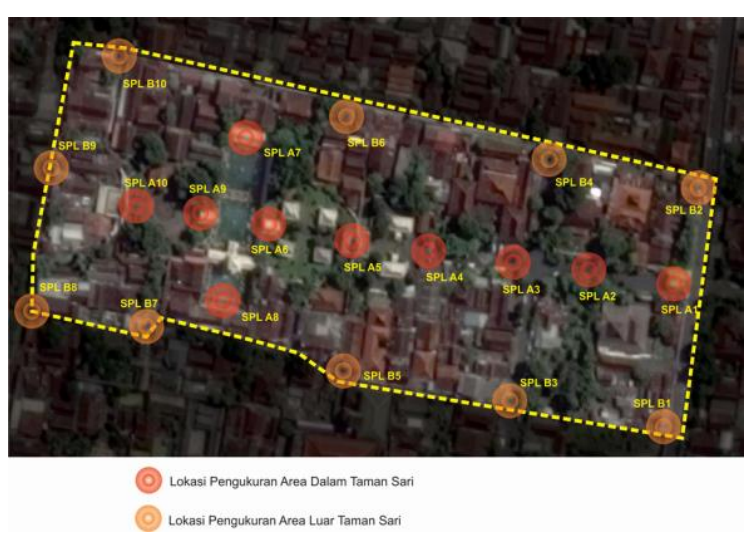

Gambar 2. Deliniasi kawasan penelitian Sumber: Noviandri, 2018

Analisis mengenai tipologi kawasan Tamansari dari masa lalu dan masa kini ditinjau melalui teori Figure Ground dan Linkage yang diberikan oleh Roger Trancik tahun 1986. Identifikasi figure ground digunakan dalam memahami blok massa bangunan dalam bentuk dimensi yang besar maupun pada bentuk dimensi massa tunggal atau kecil, serta memperlihatkan area privat dan area publik berdasarkan identifikasi bentuk enclosure solid dan void seperti solid dan void yang berbentuk core, kantong maupun jalur linear berupa korridor (Trancik, 1986).

Studi tentang figure ground mengklasifikasikan tipologi konfigurasi bentuk solid-void kedalam 6 (enam) tipologi yakni berbentuk grid, angular, curvelinear, radial concentric, axial dan organic seperti pada gambar 3 .

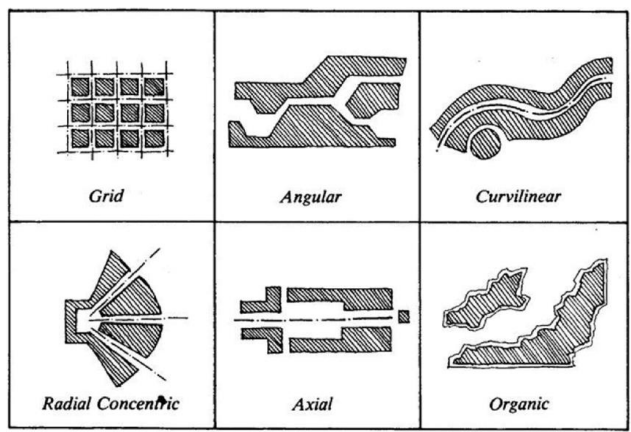

Gambar 3. Enam tipologi bentuk solid-void menurut Roger Trancik Sumber: Trancik, 1986

Soundmark yang ada di kawasan Tamansari di dapatkan melalui analisis dengan metode triangulasi data (analisis suara masa lalu), dan metode pemetaan suara (analisis suara masa kini). Dalam menemukan hubungan antara perubahan ruang dengan perubahan soundmark dilakukan metodologi komparasi/ perbandingan sehingga ditemukan makna dari sebuah lokasi (sense of place).

\section{Hasil dan Pembahasan}

Tamansari memiliki identitas kawasan yang cukup kuat. Hal ini terlihat dari bangunan Tamansari yang memiliki bentuk yang berbeda dengan bangunan-bangunan yang ada disekitarnya. Keruangan di kota Yogyakarta mengaplikasikan sistem klasifikasi Jawa yang mempunyai arti adanya hubungan antara kesatuan-kesatuan 
ruang yang diatur oleh alam semesta (Santoso, 2008). Kota Yogyakarta membagi bagian kota yang bersifat sakral di bagian Selatan sehingga bangunanbangunan yang bersifat sakral berada dibagian selatan termasuk bangunan Tamansari. Dalam mengidentifikasi perubahan ruang dan sifat sakral di kawasan tersebut, dapat dianalisis menggunakan teori figure ground dan linkage (Trancik, 1986) dari masa lalu dan masa kini.

Figure ground pada suatu kawasan ditinjau dari identifikasi bentuk solid dan void yang saling terhubung antara ruang luar dan dalam menurut aktivitasnya. Solid menjelaskan tentang karakteristik urban block yang tergambarkan menurut ukuran, tekstur, orientasi maupun komposisinya pada ruang publik. Void menjelaskan mengenai space yang bersinggungan dengan solid memiliki beberapa karakteristik keterbukaan (ruang transisi).

Linkage menjelaskan mengenai pengaturan garis yang terhubung sebagai bagian dari sebuah ruang kota dan desain ruang yang terhubung antar bangunan dengan ruang luar (Trancik, 1986). Hubungan dan dinamika dalam penataan kota dapat dilihat dari linkage yang ada di kota tersebut.

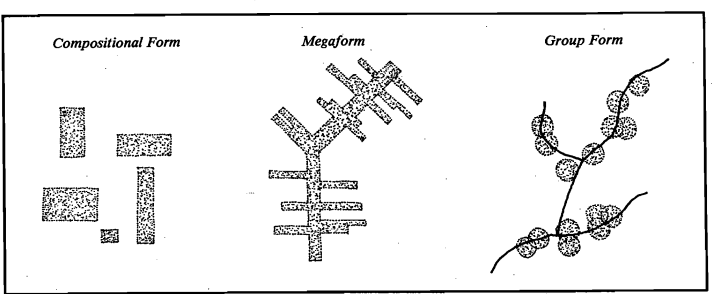

Gambar 4. Tiga tipe bentuk Linkage Sumber: Trancik, 1986

Menurut Fumihiko Maki dalam Roger Trancik (p.106-107), linkage dapat didefinisikan berdasarkan 3 (tiga) tipe bentuk linkage urban space antara lain:

(1) Compositional form merupakan bentuk linkage yang didapatkan dari bangunan yang berdiri sendiri.
(2) Mega form merupakan konfigurasi yang terhubung dengan garis lurus da hirarkis.

(3) Group form merupakan akumulasi perubahan struktur pada sepanjang ruang terbuka.

Tipe bentuk linkage ini dapat dilihat pada gambar 4. Kota tua dan bersejarah umumnya memiliki pola linkage tipe ke 3 (Group form). Hal ini disebabkan munculnya kota berdasarkan pusat-pusat kegiatan / aktivitas.

\section{A. Kawasan Tamansari Tahun 1765 - 1867}

Sejak didirikan dan digunakan pada tahun 1765-1867 karakteristik spasial Tamansari pada masa itu sangat jelas teridentifikasi sebagai fungsi privat serta memiliki nilai monumental yang sangat khas. Hal ini terlihat pada dominasi enclosure ruang yang dibatasi oleh dinding-dinding linear yang tegas sebagai pembatas antara ruang privat dan ruang disekitarnya, seperti pada gambar 5 .

Bila melihat pada perbandingan solid-void pada spasial Tamansari di masa lalu jelas terlihat bahwa area void menjadi dominan yang teridentifikasi sebagai ruang-ruang luar berupa taman atau pekarangan, jalur sirkulasi, maupun kolam air.

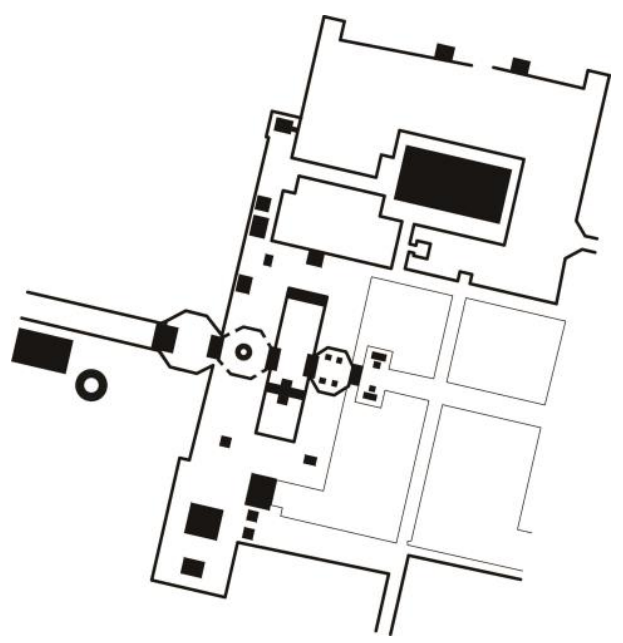

Gambar 5. Solid void area Tamansari tahun 1765-1867

Sumber:https://www.kratonjogja.id/upload/images/a ssets/4.7_2\%20Denah\%20Tamansari.jpg , $2018 \mathrm{di}$ tracing oleh penulis 
Selain itu, berdasarkan tipologi bentuk solid-void maka tipologi yang dimiliki oleh spasial Tamansari adalah axial yakni memiliki enclosure yang mengarah pada hierarki ruang berdasarkan fungsi dan aktivitasnya. Sedangkan aspek linkage yang teridentifikasi berupa compositional form dimana banyak bangunan yang berdiri sendiri dan terkesan terpisah karena berada pada dimensi atau jarak yang lebar namun hubungan ruang masih cukup jelas.
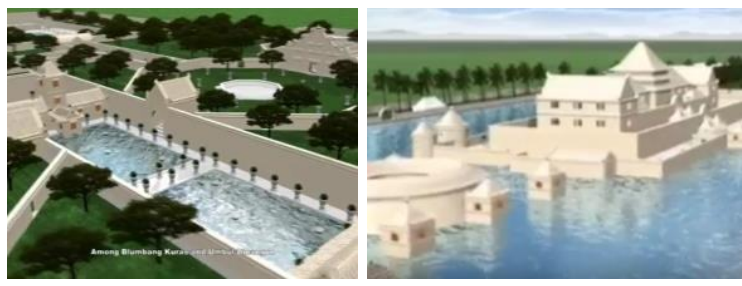

Gambar 6. Visualisasi ruang kawasan Tamansari masa lalu

Sumber: Dinas Kebudayaan Provinsi D.I. Yogyakarta, 2011

\section{B. Kawasan Tamansari Tahun 2018}

Pada Konfigurasi solid kawasan Tamansari hingga saat ini didominasi oleh bentuk massa bangunan (bangunan taman sari dan pemukiman) yang berupa block hitam dengan pattern yang kecil yang tersebar secara spasial dan organik. Sedangkan area terbuka berupa lahan kosong, ruang antar bangunan dan jalan diwakili oleh konfigurasi putih.

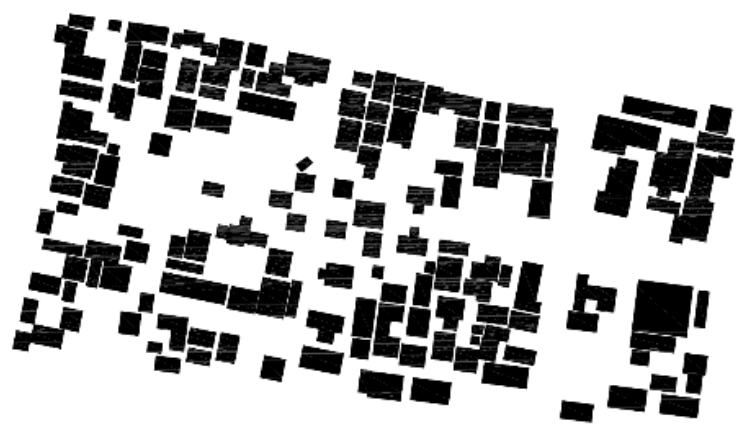

SKAL

Gambar 7. Solid void area tamansari tahun 2018 Sumber: Penulis, 2018

Dengan melihat pada tatanan konfigurasi solid void pada area penelitian maka dapat dikategorikan bahwa tekstur area
Tamansari adalah "organik" yakni dengan kecenderungan membentuk pola yang cenderung menyebar yakni pola konfigurasi yang terdiri oleh massa (solid) dan ruang (void) yang memiliki ukuran, bentuk dan kerapatan yang sangat variatif sehingga menyulitkan dalam proses identifikasi area komplek Tamansari secara dua dimensional.

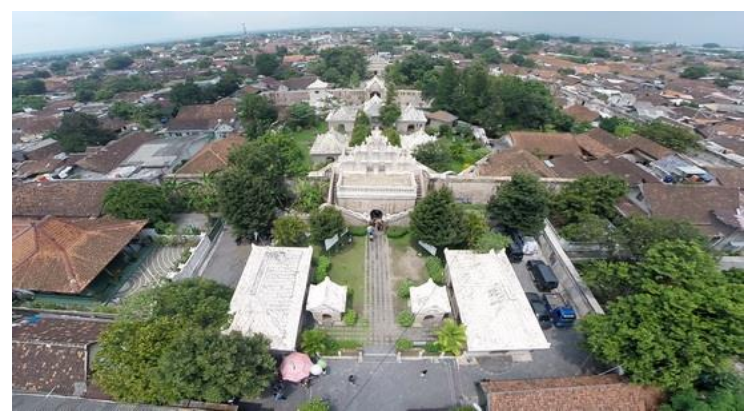

Gambar 8. Foto udara kawasan Tamansari masa kini

Sumber: BPCB D.I. Yogyakarta, 2016

\section{Identifikasi perubahan ruang kawasan Tamansari}

Ditinjau dari perbandingan antara spasial keberadaan kompleks Tamansari pada masa kini dan masa lalu maka dapat disimpulkan bahwa unsur solid-void kawasan taman sari secara keseluruhan telah berbaur atau bersinggungan langsung dengan area pemukiman. Beberapa area yang dahulu merupakan komplek Tamansari berupa ruang terbuka (taman) maupun kawasan air pada sisi utara telah berubah menjadi area pemukiman atau perkampungan yang padat sehingga memberikan kesulitan dalam mengidentifikasi pattern ataupun tipologi dalam dua dimensional. Beberapa pattern atau konfigurasi figure ground taman sari di masa lalu yang masih dapat dilihat adalah seperti pada gambar 9 .

Dengan demikian perubahan signifikan terjadi pada tipologi kawasan Tamansari yang sebelumnya teridentifikasi dengan tipe axial menjadi organic. Tipologi solid-void yang organik menggambarkan bahwa ruang kawasan taman sari mulai terbaca sebagai kawasan yang terbaca dalam dua 
dimensional tumbuh secara spontan dengan bentukan solid maupun void yang tidak memiliki enclosure yang tegas.

Perubahan tipologi kawasan yang ada di Tamansari yang diidentifikasi melalui figure ground itu menyebabkan terjadinya perubahan linkage dan place kawasan. Linkage Tamansari yang semula jelas dan hanya berupa satu jalan penghubung utama menjadi berbaur dengan kumpulan rumahrumah di kawasan tersebut. Garis penghubung pada tahun 2018 menjadi banyak cabang. Semula tipe bentuk linkage berupa megaform, saat ini menjadi compositional form. Hal ini disebabkan rumah-rumah warga yang mengisi secara organik di kawasan tesebut.

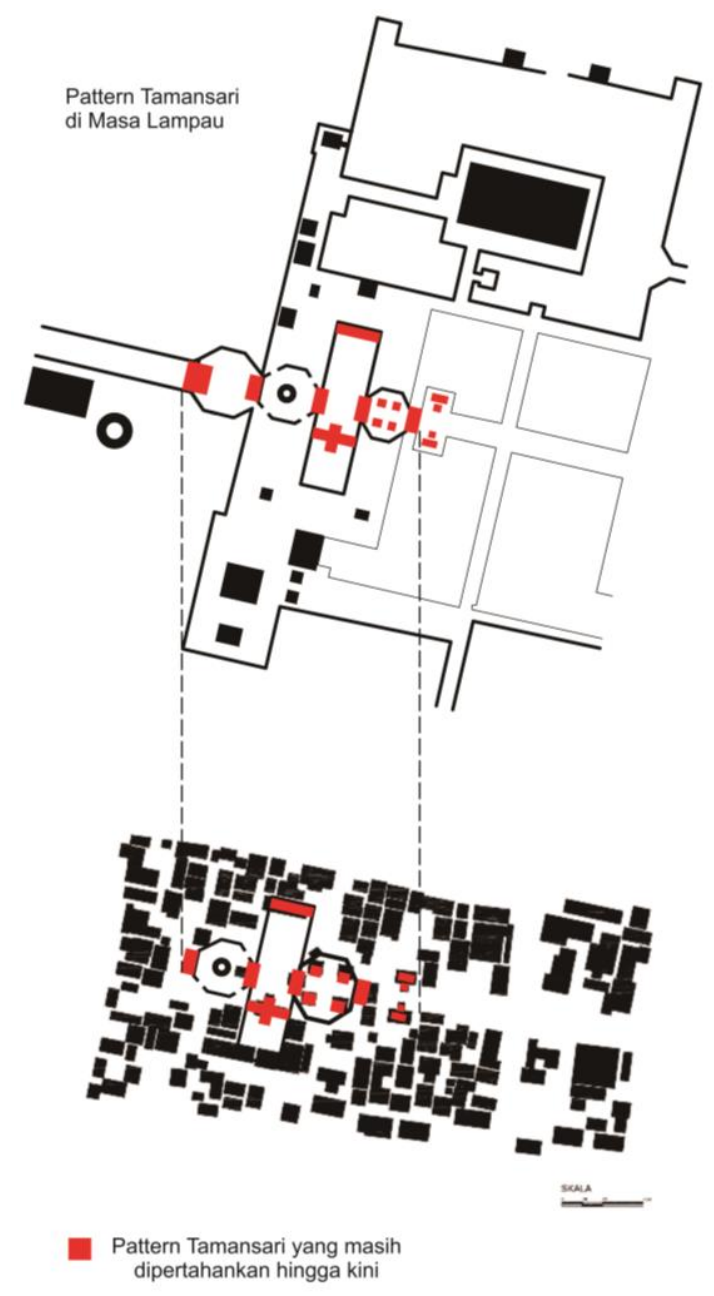

Gambar 9. Perbandingan solid void area Tamansari masa kini dan masa lalu Sumber: Peneliti, 2018
Perubahan place pada masa lalu dan saat ini menciptakan makna ruang yang berbeda. Pada masa lalu, Tamansari bersifat tertutup yang berarti hanya orang-orang tertentu yang dapat mengakses area tersebut. Menurut Santoso (2008), semua Kawasan di Kota Jawa memiliki nilai budaya dan bagian dari struktur ruang kota. Tamansari yang berada di lingkungan Keraton Yogyakarta memiliki nilai budaya yang tinggi dan termasuk dalam strukur ruang Jawa. Oleh sebab itu, pada masa lalu, Tamansari memiliki suasana sakral.

Menurut Santoso (2008), dalam sruktur ruang Jawa, kosmografi mengatur hakikat antara manusia dengan benda, termasuk hubungan manusia dengan lingkungan bangunan. Kegiatan-kegiatan yang diselenggarakan pada suatu ruang di Jawa merupakan aktualisasi hubungan antarbenda, dan antara benda dan manusia dalam menciptakan kesatuan kehidupan kemasyarakatan yang sesuai dengan hukum makrokosmos. Perubahan ruang pada kawasan Tamansari mengakibatkan perubahan akustiknya.

Tabel 1. Perubahan space Tamansari

\begin{tabular}{|c|c|c|}
\hline Waktu & 1765 - 1867 & 2018 \\
\hline $\begin{array}{l}\text { Figure } \\
\text { Ground }\end{array}$ & $\begin{array}{l}\text { Dominan } \\
\text { Void (berupa } \\
\text { taman dan } \\
\text { kolam), axial }\end{array}$ & $\begin{array}{l}\text { Dominan solid } \\
\text { (berupa rumah } \\
\text { penduduk), } \\
\text { organik }\end{array}$ \\
\hline Linkage & $\begin{array}{l}\text { Jelas, linkage } \\
\text { utama hanya } \\
1, \text { termasuk } \\
\text { tipe } \\
\text { megaform, } \\
\text { arah masuk } \\
\text { melalui pintu } \\
\text { barat }\end{array}$ & $\begin{array}{l}\text { Linkage utama } \\
\text { masih jelas } \\
\text { tetapi berbaur } \\
\text { dengan } \\
\text { kumpulan solid } \\
\text { permukiman, } \\
\text { termasuk tipe } \\
\text { compositional } \\
\text { form, arah } \\
\text { masuk melalui } \\
\text { pintu timur }\end{array}$ \\
\hline Place & $\begin{array}{l}\text { Bersifat } \\
\text { tertutup, } \\
\text { keunikan pada } \\
\text { suasana sakral } \\
\text { dan khusus }\end{array}$ & $\begin{array}{l}\text { Bersifat terbuka, } \\
\text { keunikan pada } \\
\text { suasana wisata }\end{array}$ \\
\hline
\end{tabular}

Sumber : Analisis, 2018 
Pada masa kini, kawasan Tamansari menjadi kampung wisata pusaka yang terbuka bagi pengunjung. Apabila dilihat secara keruangan (place) maka tekstur dan warna bangunan Tamansari masih memudahkan dalam mengidentifikasi keberadaanya. Selain itu sense of place yang dimiliki oleh kompleks Tamansari memberikan nilai yang berbeda yakni saat ini sebagai bangunan atau kawasan cagar budaya dengan aktivitas wisata sehingga hal inilah yang membuat kompleks taman sari dapat dikenali sebagai landmark kawasan walaupun berada pada area yang padat pemukiman.

\section{Perubahan ruang yang berpengaruh pada soundmark kawasan heritage Tamansari}

Pada masa lalu, suara yang lebih banyak terdengar merupakan suara alam dan suara manusia (Noviandri, 2018). Suara alam berupa suara angin, suara air kolam dan air di pancuran, suara gesekan dedaunan pada pohon. Pada masa itu belum banyak kendaraan bermotor. Keluarga Keraton datang ke Tamansari melalui bagian dalam Tamansari (gapura barat) menggunakan kereta kuda / kuda / berjalan. Suara-suara tersebut pada masa lalu tergolong suara yang memberikan pengaruh positif pada pendengar dan memiliki tingkat kekerasan sangat lemah (tabel 3).

Hal ini didukung dari Saputra (2016) yang menjelaskan prinsip suara yang mempengaruhi kondisi batin pengguna ruang yaitu semakin tinggi intensitas suara dari ruang sumber suara, maka semakin kuat daya pengaruh suara dalam mempengaruhi pengguna ruang. Prinsip ke dua menurut Saputra (2016) yaitu suara yang harmonis memberikan pengaruh positif terhadap kondisi batin pendengarnya, sebaliknya suata yang tidak harmonis merupakan polusi suara yang mengakibatkan dampak buruk bagi pendengarnya.
Berbeda dengan masa kini, Tamansari di dominasi dengan suara kendaraan bermotor dan aktivitas wisata (Noviandri, 2018). Suara kendaraan bermotor merupakan suara yang membuat tingkat kebisingan di kawasan Tamansari menjadi tinggi (mencapai $74 \mathrm{~dB}$ ). Suara-suara tersebut merupakan suara yang membuat ketidaknyamanan di telinga manusia (tabel 2).

\section{Tabel 2. Perbandingan tingkat bunyi}

\begin{tabular}{|c|c|c|}
\hline dB & $\begin{array}{c}\text { Contoh } \\
\text { Sumber } \\
\text { Suara }\end{array}$ & $\begin{array}{l}\text { Penilaian } \\
\text { Subyektif }\end{array}$ \\
\hline$>130$ & $\begin{array}{l}\text { Pesawat } \\
\text { tinggal landas } \\
\text { dan mesin jet }\end{array}$ & $\begin{array}{l}\text { Menyakitkan } \\
\text { dan Berbahaya }\end{array}$ \\
\hline $\begin{array}{c}100- \\
130\end{array}$ & $\begin{array}{lr}\text { Sepeda } & \text { motor } \\
\text { digas } & \text { pada } \\
\text { jarak } 1 & \text { meter, } \\
\text { band } & \text { hard } \\
\text { rock } & \end{array}$ & Memekakkan \\
\hline $80-100$ & $\begin{array}{l}\text { Ruang } \\
\text { peralatan } \\
\text { komputer, } \\
\text { pemecah } \\
\text { beton dengan } \\
\text { tekanan, mesin } \\
\text { percetakan, } \\
\text { suara gaduh } \\
\text { penonton } \\
\text { sepakbola, } \\
\text { klakson mobil }\end{array}$ & Sangat Keras \\
\hline $60-70$ & $\begin{array}{l}\text { Lalu lintas } \\
\text { jalan raya, } \\
\text { kabin pesawat } \\
\text { saat terbang }\end{array}$ & Keras \\
\hline $40-60$ & $\begin{array}{l}\text { Lalu lintas } \\
\text { jalan raya, } \\
\text { kegiatan } \\
\text { kantor, musik } \\
\text { lembut tanpa } \\
\text { bunyi stereo }\end{array}$ & Sedang \\
\hline $20-40$ & $\begin{array}{l}\text { Rumah tinggal } \\
\text { tanpa bunyi } \\
\text { stereo malam } \\
\text { hari, bisikan }\end{array}$ & Lemah \\
\hline $0-20$ & $\begin{array}{l}\text { Bunyi daun } \\
\text { terkena angin } \\
\text { lembut, nafas } \\
\text { manusia, } \\
\text { ruang } \\
\text { pengujian } \\
\text { audiometrik }\end{array}$ & Sangat Lemah \\
\hline
\end{tabular}


Suara air yang menjadi ikon dari Tamansari tertutup dengan suara kebisingan kendaraan, suara tawa, dan teriakan manusia. Jenis sumber suara yang ada di Tamansari sesuai zona yang diamati dapat dilihat pada tabel 3 .

Kawasan Tamansari memiliki tingkat suara antara $45 \mathrm{~dB}$ sampai dengan $74 \mathrm{~dB}$. Tingkat suara paling rendah di zona B8 yang merupakan batas terluar (barat laut) dari Kawasan Tamansari. Tingkat suara yang rendah disebabkan di daerah tersebut hanya penduduk yang ada disana, jarak antar bangunan berhimpitan dan ada jalan yang dapat digunakan hanya untuk motor. Zona B8 tidak digunakan sebagai akses keluar wisatawan Kawasan Tamansari.

Tingkat suara paling tinggi di zona A1. Hal ini disebabkan zona ini merupakan pintu masuk dari wisatawan Tamansari. Pintu masuk ini digunakan untuk kendaraan yang ingin parkir di dalam Tamansari. Lokasi ini semakin tinggi tingkat suaranya ketika penduduk memulai ibadah di masjid yang berada di barat pintu masuk kawasan Tamansari.

Tabel 3. Sumber suara dan tekanan suara kawasan Tamansari tahun 2018

\begin{tabular}{|c|l|l|}
\hline Zona & \multicolumn{1}{|c|}{ Sumber Suara } & \multicolumn{1}{|c|}{$\begin{array}{c}\text { Tingkat } \\
\text { Suara }\end{array}$} \\
\hline A1 & $\begin{array}{l}\text { suara yang berasal dari } \\
\text { kendaraan bermotor (knalpot } \\
\text { dan mesin), suara langkah } \\
\text { kaki, suara manusia, suara } \\
\text { penjual es krim }\end{array}$ & \\
\hline A2 & $\begin{array}{l}\text { suara yang berasal dari } \\
\text { kendaraan bermotor (knalpot } \\
\text { dan mesin), suara manusia, } \\
\text { suara adzan }\end{array}$ & \\
\hline A3 & $\begin{array}{l}\text { suara yang berasal dari } \\
\text { kendaraan bermotor (knalpot, } \\
\text { klakson dan mesin), suara } \\
\text { teriakan anak kecil, suara } \\
\text { mangkok, suara musik penjual } \\
\text { es krim, suara musik }\end{array}$ & \\
\hline A4 & $\begin{array}{l}\text { suara manusia, suara langkah } \\
\text { kaki manusia, suara yang } \\
\text { berasal dari kendaraan } \\
\text { bermotor (mesin), suara pintu } \\
\text { mobil tertutup }\end{array}$ & \\
\hline
\end{tabular}

\begin{tabular}{|c|c|c|}
\hline Zona & Sumber Suara & $\begin{array}{l}\text { Tingkat } \\
\text { Suara }\end{array}$ \\
\hline A5 & $\begin{array}{l}\text { suara manusia (teriak dan } \\
\text { berbicara keras) suara orang } \\
\text { jalan, suara aktivitas buang } \\
\text { sampah (pekerja tamsar), } \\
\text { suara yang berasal dari } \\
\text { kendaraan bermotor (mesin) }\end{array}$ & $60 \mathrm{~dB}$ \\
\hline A6 & $\begin{array}{l}\text { suara / aktivitas pengunjung, } \\
\text { suara langkah kaki, suara air, } \\
\text { suara kicauan burung, gema } \\
\text { suara manusia pada selasar }\end{array}$ & $64 \mathrm{~dB}$ \\
\hline A7 & $\begin{array}{l}\text { suara manusia, suara langkah } \\
\text { kaki, suara air mancur }\end{array}$ & $60 \mathrm{~dB}$ \\
\hline A8 & $\begin{array}{l}\text { suara manusia, suara pancuran } \\
\text { air mengisi kolam }\end{array}$ & $58 \mathrm{~dB}$ \\
\hline A9 & $\begin{array}{l}\text { suara burung, suara manusia, } \\
\text { suara langkah kaki, suara } \\
\text { gesekan daun di pohon, suara } \\
\text { musik es podlepop, suara } \\
\text { angin }\end{array}$ & $56 \mathrm{~dB}$ \\
\hline A10 & $\begin{array}{l}\text { Suara manusia (bicara dengan } \\
\text { keras, tertawa), suara yang } \\
\text { berasal dari kendaraan } \\
\text { bermotor (mesin) }\end{array}$ & $60 \mathrm{~dB}$ \\
\hline B1 & $\begin{array}{l}\text { suara adzan, suara yang } \\
\text { berasal dari kendaraan } \\
\text { bermotor (mesin, knalpot } \\
\text { racing, klakson), suara } \\
\text { manusia, suara hentakak kaki } \\
\text { kuda (andong), orang } \\
\text { pengendara, lonceng cilok }\end{array}$ & $71 \mathrm{~dB}$ \\
\hline B2 & $\begin{array}{l}\text { suara yang berasal dari } \\
\text { kendaraan bermotor (knalpot } \\
\text { biasa, knalpot racing, klakson } \\
\text { dan mesin), suara musik es } \\
\text { krim walls, suara klakson } \\
\text { terompet tukang roti, suara } \\
\text { delmansuara adzan }\end{array}$ & $71 \mathrm{~dB}$ \\
\hline B3 & $\begin{array}{l}\text { suara burung, suara langkah } \\
\text { kaki, suara yang berasal dari } \\
\text { kendaraan bermotor (mesin), } \\
\text { suara angin }\end{array}$ & $58 \mathrm{~dB}$ \\
\hline B4 & $\begin{array}{l}\text { suara yang berasal dari } \\
\text { kendaraan bermotor (mesin), } \\
\text { suara burung berkicau, lagu } \\
\text { gamelan, suara langkah kaki, } \\
\text { suara manusia, suara atap } \\
\text { seng terkena angin }\end{array}$ & $60 \mathrm{~dB}$ \\
\hline B5 & $\begin{array}{l}\text { suara yang berasal dari } \\
\text { kendaraan bermotor (mesin), } \\
\text { suara bel, suara langkah kaki, } \\
\text { suara burung, suara manusia, } \\
\text { suara plastik terbawa angin }\end{array}$ & $54 \mathrm{~dB}$ \\
\hline B6 & $\begin{array}{l}\text { suara manusiaa, kicauan } \\
\text { burung, suara langkah kaki, } \\
\text { suara gesekan daun tertiup } \\
\text { angin, suara tokek, suara } \\
\text { adzan }\end{array}$ & $54 \mathrm{~dB}$ \\
\hline
\end{tabular}




\begin{tabular}{|c|c|c|}
\hline Zona & Sumber Suara & $\begin{array}{c}\text { Tingkat } \\
\text { Suara }\end{array}$ \\
\hline B7 & $\begin{array}{l}\text { suara manusia, suara langkah } \\
\text { kaki, suara yang berasal dari } \\
\text { kendaraan bermotor (mesin), } \\
\text { suara burung berkicau, suara } \\
\text { sepeda, suara gesekan daun } \\
\text { yang tertiup angin, suara anak } \\
\text { bayi berteriak (dari dalam } \\
\text { rumah), suara adzan }\end{array}$ & $57 \mathrm{~dB}$ \\
\hline B8 & $\begin{array}{l}\text { suara yang berasal dari } \\
\text { kendaraan bermotor (mesin), } \\
\text { suara manusia, suara orang } \\
\text { menyapu dengan sapu lidi, } \\
\text { suara ayam, suara burung } \\
\text { peliharaan }\end{array}$ & $45 \mathrm{~dB}$ \\
\hline B9 & $\begin{array}{l}\text { Suara langkah kaki, suara } \\
\text { gesekan sandal, suara kucing, } \\
\text { suara yang berasal dari } \\
\text { kendaraan bermotor (mesin), } \\
\text { suara orang }\end{array}$ & $49 \mathrm{~dB}$ \\
\hline B10 & $\begin{array}{l}\text { suara yang berasal dari } \\
\text { kendaraan bermotor (mesin), } \\
\text { suara manusia (meng, suara } \\
\text { burung yang menukik, suara } \\
\text { orang, suara teriakan, suara } \\
\text { jangkrik }\end{array}$ & $57 \mathrm{~dB}$ \\
\hline
\end{tabular}

Sumber : Penulis, 2018

Ditinjau melalui aspek akustik, suara terjadi akibat intervensi kegiatan seperti aktivitas pemukiman, kendaraan bermotor, aktivitas wisatawan dan lain sebagainya yang menyebabkan soundmark pada lingkungan tersebut berubah. Soundmark pada kawasan ini menjadi berubah. Pada masa lalu soundmark di kawasan Tamansari merupakan suara-suara yang mendukung makna sakral pada ruang utama. Pada saat ini soundmark berubah menjadi suara keramaian aktivitas manusia yang berasal dari kendaraan bermotor dan aktivitas wisata (suara langkah kaki manusia).

Tabel 4. Perbandingan ruang dan suara pada tahun 1867 dan tahun 2018

\begin{tabular}{|c|c|c|}
\hline & $<1867$ & 2018 \\
\hline 承 & $\begin{array}{l}\text { Lansekap } \\
\text { didominasi } \\
\text { taman dan } \\
\text { kolam }\end{array}$ & $\begin{array}{l}\text { Lansekap } \\
\text { didominasi rumah } \\
\text { penduduk (solid) }\end{array}$ \\
\hline
\end{tabular}

\begin{tabular}{|c|c|c|}
\hline 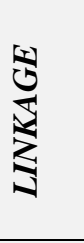 & $\begin{array}{l}\text { Bersifat } \\
\text { tertutup khusus } \\
\text { diakses oleh } \\
\text { keluarga } \\
\text { kerajaan dan } \\
\text { abdi dalem }\end{array}$ & $\begin{array}{l}\text { Bersifat terbuka } \\
\text { yaitu setiap orang } \\
\text { bisa masuk }\end{array}$ \\
\hline$\frac{5}{5}$ & $\begin{array}{l}\text { Sakral, } \\
\text { Khusus, Privat }\end{array}$ & $\begin{array}{l}\text { Ramai, Umum, } \\
\text { Publik }\end{array}$ \\
\hline 点 & $\begin{array}{l}\text { Suara tenang, } \\
\text { Suara gesekan, } \\
\text { suara bernada } \\
\text { (musik) }\end{array}$ & $\begin{array}{lr}\text { Suara } & \text { kendaraan } \\
\text { bermotor, } & \text { Suara } \\
\text { gesekan, } & \text { suara } \\
\text { benturan, } & \text { suara } \\
\text { teriakan, suara anak } \\
\text { berlari }\end{array}$ \\
\hline 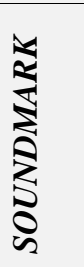 & $\begin{array}{l}\text { Suara-suara } \\
\text { alam, dan } \\
\text { musik yang } \\
\text { mendukung } \\
\text { suasana sakral }\end{array}$ & $\begin{array}{l}\text { Suara-suara } \\
\text { keramaian aktivitas } \\
\text { manusia }\end{array}$ \\
\hline
\end{tabular}

Sumber : Analisis, 2018

Soundmark merupakan suara yang unik yang perlu untuk dilestarikan atau dijaga. Dalam konteks kawasan heritage, Tamansari memiliki kekhasan yang perlu dilestarikan dalam hal suara, yang kurang disentuh dalam usaha konservasi. Suara dalam kawasan heritage merupakan salah satu intangible culture yang perlu diperhatikan dan dilestarikan (Noviandri, 2017).

Tamansari telah melakukan berbagai macam kegiatan konservasi. Namun, konservasi yang dilakukan terbatas hanya konservasi fisik kawasan (beautifikasi). Konservasi ruang tidak dapat dilakukan hanya dalam satu aspek saja, melainkan secara komprehensif.

Suasana spesifik dalam konsep ruang kota heritage, elemen suara mampu menciptakan memori pada masa lalu. Dengan adanya elemen suara yang di konservasi, suasana dalam ruang heritage tersebut menjadi bermakna (intangible culture terjaga). Ruang akan menjadi place apabila 
diberikan makna kontekstual dari aspek budaya atau potensi lokal (Trancik, 1986). Makna ruang ini memberikan sense of place semakin terlihat dan mampu dirasakan oleh penghuni. Sehingga keruangan Tamansari dapat dilihat secara menyeluruh dimana lokasi Tamansari merupakan ruang yang memiliki keunikan, baik dari warna, tekstur, maupun pemaknaan didalam tempat tersebut.

Perubahan soundmark akibat perubahan bentuk ruang membuat manusia di kawasan tersebut sulit mengenali kawasan pada masa lalu. Hal ini menyebabkan pada suatu saat orang hanya mengenal bahwa Tamansari merupakan tempat wisata seperti tempat wisata lain. Tamansari perlu meningkatkan kekhasannya meskipun telah berubah dengan banyaknya bangunan disekitarnya.

Desain kawasan yang komprehensif dengan memperhatikan elemen fisik dan non-fisik akan menciptakan suasana spesifik yang mengadaptasi dengan kegiatan yang sudah ada di kawasan tersebut. Soundmark sebagai elemen non-fisik akan mampu memperkuat makna Kawasan yang menimbulkan dampak Long Term Memory (LTM) bagi siapa saja yang datang dan tinggal di lokasi tersebut.

\section{Kesimpulan}

Ruang-ruang di kota Yogyakarta yang merupakan ruang kota pusaka yang penuh dengan makna. Ruang yang telah berubah sesuai perkembangan jaman akan mempengaruhi makna yang ada dalam ruang kota Yogyakarta yang membentuk suatu identitas kawasan.

Perubahan ruang kawasan Tamansari terlihat pada figure ground dan linkage. Perubahan berupa dari kawasan yang voidnya lebih dominan menjadi solid lebih dominan. Hal ini menyebabkan linkage kawasan berubah sehingga makna dari place berubah. Perubahan figure ground yang menyebabkan fungsi Kawasan berubah memberikan dampak yang besar bagi soundmark yang ada di kawasan Tamansari. Soundmark kawasan berubah dari suara-suara yang mendukung suasana sakral dengan suara-suara keramaian aktivitas manusia.

Penelitian ini memberikan rekomendasi dalam pengelolaan aktivitas Tamansari yang berkaitan dengan konservasi kawasan pusaka, permukiman, dan wisata budaya. Dalam hal konservasi kawasan heritage, perlu memaknai ruang secara komprehensif baik elemen fisik maupun non-fisik. Soundmark merupakan elemen non-fisik dalam suatu kawasan yang memberikan identitas kawasan.

Soundmark yang dimunculkan sebaiknya aktivitas manusia baik penghuni maupun wisatawan, yang mendukung kawasan wisata budaya. Soundmark pada masa lalu sebaiknya diperkuat intensitas suaranya sehingga wisatawan menemukan sense of place Tamansari pada masa lalu. Makna dari kawasan akan tersampaikan dalam Long Term Memory wisatawan yang ada di dalamnya ketika merancang sebuah kawasan konservasi dengan menguatkan soundmark sebagai elemen non-fisiknya.

\section{Ucapan Terima Kasih}

Terima kasih disampaikan kepada Kemenristek DIKTI dan LPPM Universitas Kristen Duta Wacana atas dana dan dukungan dalam penyelesaian penelitian Hibah PDP Dikti dengan Nomor : 009/HBLIT/II/2018.

Terimakasih disampaikan pula kepada pihak Keraton Yogyakarta melalui sekretariat Tamansari yang memberikan ijin dalam melakukan penelitian ini. Penulis berterimakasih pula kepada warga Kawasan Tamansari, semua narasumber, dan surveyor yang terkait dengan pengambilan data penelitian ini. 


\section{Daftar Pustaka}

Adishakti, L. T. (1997). A study on the conservation planning of Yogyakarta historic-tourist city based on urban space heritage conception (Doctoral Disertation Kyoto University, 1997. Tidak dipublikasikan).

Noviandri, P.P. (2017). Soundscape mapping in heritage area: (Case Study: 'Legi' Market, Kotagede, Yogyakarta, Indonesia). Proceeding Wuicace The 1 st Warmadewa University International Conference on Architecture and Civil Engineering, $275-282$.

Noviandri, P.P. dan Sabono, F. (2018). Adaptasi bangunan cagar budaya Tamansari Yogyakarta terhadap perkembangan zaman melalui soundscape. Prosiding Seminar Archimariture IPLBI, A078 - 086.

Santoso, Jo. (2008). Arsitektur-kota Jawa: Kosmos, kultur dan kuasa. Jakarta: Centropolis.

Saputra, Andika. (2016). Dimensi suara dalam ruang: Tinjauan psikologi arsitektur.

https://www.academia.edu/37512940/ Dimensi_Suara_Dalam_Ruang_Tinja uan_Psikologi_Arsitektur?auto=down load, diakses tanggal 26 April 2019.

Satwiko, Prasasto. (2004). Fisika bangunan 1 edisi 1. Yogyakarta: Andi Offset.

Schafer, R. Murray. (1994). The soundscape: Our sonic environment and the tuning of the world. Rochester: Destiny Books.

Subhekti, Y.I. (2005). Perkembangan Tamansari sebagai kawasan konservasi dan pariwisata Kota Yogyakarta (Tesis Magister Teknik Pembangunan Wilayah dan Kota, Universitas Diponegoro Semarang, 2005. Tidak dipublikasikan).

Synder, Bob. (2000). Music and memory: An introduction. London: The MIT Press.
The Burra Charter. (2013). The Australia ICOMOS charter for places of cultural significance. Australia: Australia ICOMOS Incorporated.

Trancik, R. (1986). Finding lost space. theories of urban design. New York: Van Nostrand Reinhold Company.

Undang-Undang Republik Indonesia Nomor 11 Tahun 2010 tentang Cagar Budaya. Pasal $9-10$.

Van de Ven, C. (1991). Ruang dalam arsitektur. Jakarta: Gramedia Pustaka Utama.

Winarni, F. (2006). Aspek hukum upaya pelestarian situs Tamansari Yogyakarta sebagai salah satu warisan budaya. Mimbar Hukum Volume 18, Nomor 2, Juni 2006, 159292.

Zhou, Min. (2014). Research on soudmarks of soundscape at historical district. Applied Mechanics and Materials Vols. 584-586, 521 - 524. 